Iğdır Üniversitesi Fen Bilimleri Enstitüsü Dergisi, 11(Özel Sayı): 3447-3454, 2021

Journal of the Institute of Science and Technology, 11(Special Issue): 3447-3454, 2021

ISSN: 2146-0574, eISSN: 2536-4618

Bahçe Bitkileri / Horticulture

DOI: $10.21597 /$ jist.1027411

Derleme Makalesi / Review Article

Geliş tarihi / Received: 23.11.2021

Kabul tarihi / Accepted: 10.12.2021

Atıf İçin: Ermiş S, Öktem G, 2021. Ülkemizde Tescilli Sebze Çeşitlerinin Mevcut Durumu ve Tescil Sistemi. Iğdır Üniversitesi Fen Bilimleri Enstitüsü Dergisi, 11(Özel Say1): 3447-3454.

To Cite: Ermis S, Oktem G, 2021. Current Status and Registration System of Vegetable Varieties in Our Country. Journal of the Institute of Science and Technology, 11(Special Issue): 3447-3454.

\title{
Ülkemizde Tescilli Sebze Çeşitlerinin Mevcut Durumu ve Tescil Sistemi
}

\section{Sitk1 ERMİ̧ ${ }^{1 *}$, Güleda ÖKTEM ${ }^{1}$}

ÖZET: Tarımsal üretimin başlangıcı ve birçok bitkinin çoğaltım materyali olan tohum, ülkelerin tarım ve gıda sektörleri için stratejik bir öneme sahiptir. Yetiştiricilikte kullanılan diğer tüm üretim girdileri sadece tohumluğun üretim potansiyelini gerçekleştirmeye yardımcı olmaktadır. Sebze tohumculuğunda özellikle son yıllarda yüksek kalite ön plana çıkmış olup tohumdan beklenen çeşit özellikleri hem üretici hem de tüketici açısından önemli hale gelmiştir. Sebze sslah faaliyetleri sonucunda geliştirilmiş ve 1964 yılından günümüze kadar kayıt altına alınmış sebze çeşitleri özellikle son 20 yılda hızlı bir ivme ile büyüyerek hem ulusal hem de uluslararası pazarda önemli bir hale gelmiştir. Bu çalışmada, sebze üretim miktarı bakımından dünyada önemli bir yere sahip olan ülkemizin sebze tohumculuğu açısından irdelenmesi ve mevcut durumu ile birlikte sebze tescil sistemi ele alınmıştır.

Anahtar Kelimeler: Tohum, Tescil, UPOV, Sebze, Islah

\section{Current Status and Registration System of Vegetable Varieties in Our Country}

ABSTRACT: The seed, which is the beginning of agricultural production and the propagation material of many plants, has a strategic importance for the agriculture and food sectors of the countries. All other production inputs used in growing only help to realize the production potential of the seed. Especially in recent years, high quality has come to the fore in vegetable seeds, and the variety characteristics expected from the seed have become important for both the producer and the consumer. Vegetable varieties developed as a result of vegetable breeding activities and recorded since 1964 have grown rapidly, especially in the last 20 years, and have become important in both national and international markets. In this study, our country which has an important place in the world in terms of vegetable production has been evaluated with regard tovegetable seeds, and the registration system and its current situation are discussed.

Keywords: Seed, Registration, UPOV, Vegetable, Breeding

\footnotetext{
${ }^{1}$ Sıtkı ERMİŞ (Orcid ID: 0000-0003-4919-921X), Güleda ÖKTEM (Orcid ID: 0000-0002-1749-4903), Tohumluk Tescil ve Sertifikasyon Merkez Müdürlüğü-Yenimahalle/ANKARA

*Sorumlu Yazar/Corresponding Author: Sitk1 ERMİş, e-mail: seedman37@gmail.com

Makale Uluslararası katılımlı 7. Tohumculuk Kongresi, 15-17 Kasım, Iğdır sözlü olarak sunulmuştur.
} 


\section{GİRiş}

Tohum, tarımsal üretimin temel girdilerinin başında gelmekte olup, kaliteli tohum kullanımı; verimi ve üretimi artırmasının yanı sıra daha dayanıklı, daha az maliyetli ve rekabet gücü yüksek ürünlerin elde edilmesi bakımından büyük önem taşımaktadır.

Dünyada tohumculuk faaliyetlerinin endüstriye dönüşmesi 20. yüzyılın ilk yıllarında başlamış olup ülkemize göre en az 100 yıl öncesinden bu faaliyetler gündeme gelmiştir. 1950'li y1llarda genetik bilimi, sistematik bitki ıslahı ile çeşit geliştirme faaliyetlerinin gelişmesi ve 1970'li yıllarda bitki ıslahçı hakları sisteminin oluşturulması ile birlikte tohumculuğun gelişimi hızlı bir ivme kazanmıştır.

Özellikle 20'nci yüzyılın sonunda modern biyoteknoloji ve rekombinant DNA teknolojileri ile sebze tohumculuğundaki gelişim daha da artmıştır. 1970'li yıllarda yaklaşık 1 milyar dolar olan tohum ticareti, 1980'li yılların ortasından itibaren hızla artmaya başlamış, 2012 yılı ISF (Uluslararası Tohum Ticareti Federasyonu) verilerine göre küresel tohum üretim değeri 44.9 milyar dolar olarak gerçeklemiş olup, ABD (\%26.7) ve Çin (\%22.1) ilk iki sırada yer almıştır. Bugün itibariyle dünya tohumluk üretim değeri yaklaşık 62.9 milyar dolar olarak belirlenmiştir (Anonim, 2021a). Bu artış trendi halen aynı hızla devam etmekte olup, uluslararası tohum ticaretinin en önemli ayağını sırasıyla Hollanda, Fransa, ABD ve Almanya oluşturmaktadır (TİGEM, 2019). Ülkemiz ise bugün dünya tohum ticaretinde 13. sırada yer almaktadır (TÜRKTOB 2020).

Toplam tohumluk artışındaki payın yaklaşık \%80'ini hububat ve yağlı tohum bitkilerin oluşturduğu, küresel tohum pazarındaki sebze tohum payının yaklaşık \%20 olduğu ve önümüzdeki dönem sebze tohumu pazarının \%8.70'lik bir ortalama artış kaydetmesi beklendiği ifade edilmektedir. (TÜRKTED, 2019). Dünya'da 2019 yılı itibariyle yaklaşık 14.10 milyon ton tohum, dış ticarete dâhil olmuştur. Bunun 7.257 milyon tonu ihracat, 6.841 milyon tonu ise ithalatı oluşturmaktadır. 2019 yılı itibariyle toplam 278.276 ton sebze tohumu diş ticarete konu olmuş bunun 139.087 tonu ihracat, 137.189 tonu ise ithalat olarak gerçekleşmiştir. Dünya sebze tohumu ihracatının \%71'i ile ithalatının \%60'ının 10 ülke tarafından gerçekleştirildiği ve Hollanda'nın ilk sırada yer aldığ görülmektedir (Şekil 1). Ülkemiz ise dünya sebze tohum ticaretinde ihracat bakımından 7.826 ton ile 8 . sirada, ithalat bakımından ise 4.096 ton ile 10. sirada yer almaktadir (Anonim, 2019).

Ülkelerin 2019 yllı tohum ihracatı (ton)
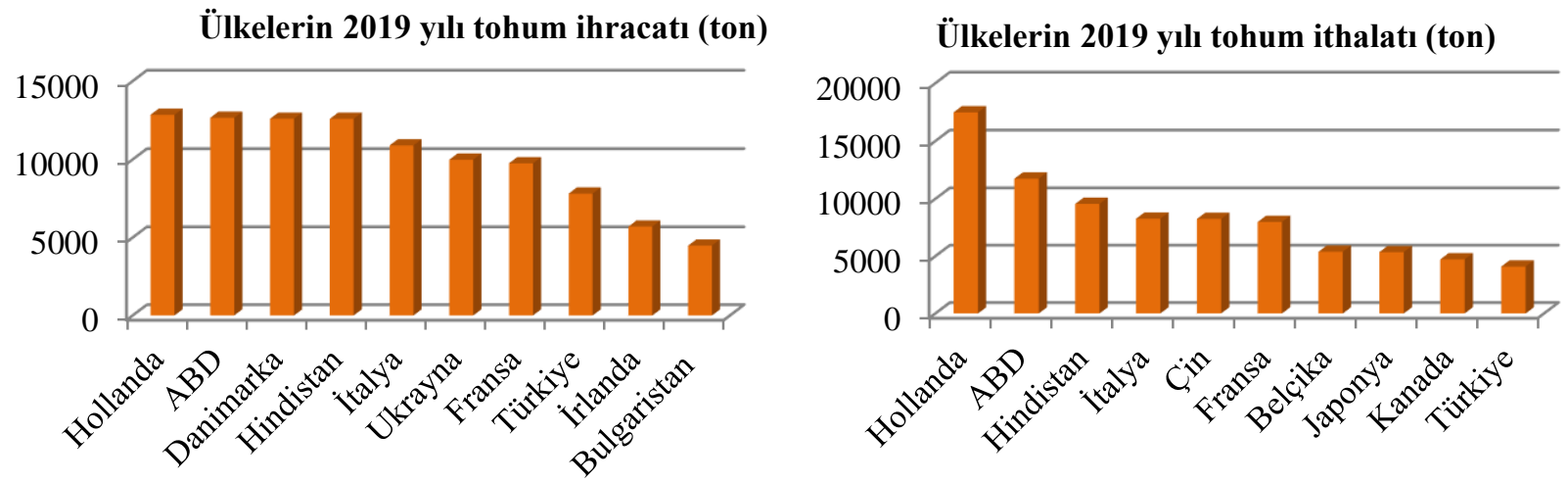

Şekil 1.Ülkelerin 2019 y1lı sebze tohum ihracat ve ithalat verileri (Anonim, 2019).

Dünya tohum endüstrisindeki gelişmeler tarihsel olarak incelendiğinde ilk tohumluk laboratuvarı 1869 yılında Almanya, 1871'de Danimarka ve 1876'da ise Amerika Birleşik Devletleri'nde kurulmuştur. 1906 yılında Avrupa Tohumluk Kontrol Birliği (ESTA), 1908 yılında ABD ve Kanada tarafından Resmi Tohumluk Sertifikasyon Ajansları Birliği (AOSCA), 1924 yılında Uluslararası Tohum Test Birliği (ISTA) ve Uluslararası Tohum Ticareti Federasyonu (ISF), 1958 yılında ise Ekonomik Kalkınma ve İşbirliği Teşkilatı (OECD) kurulması şeklinde sıralanmaktadır. 
Ülkemizde bitkisel üretimi çeşitlendirme ve bu çeşitleri iç ve dış pazarlara sunma çalışmalarının Osmanlı'ya kadar dayandığı bilinmektedir (Anonim, 2016). 1839 y1lında Osmanlı'da bitkisel üretimi artırma, çeşitlendirme ve ihracat gelirleri elde etmede yeni türler, yeni bitki çeşitleri ve kaliteli tohumun önemi fark edilmiş, Tanzimat devri ile birlikte ziraat alanında yeniden yapılanmaya gidilmiştir. 1860 yılında ABD ve Mısır'dan pamuk tohumluğu ithal edilmiş Ege ve Çukurova bölgelerine dağıtılmıştır. 1881 yılında Edirne' de ziraat okulunun açılmasıyla eğitim atağı ivme kazanmıştır (TURKTED, 2019).

Cumhuriyetin ilk yıllarında Adapazarı, Eskişehir ve Yeşilköy daha sonraki yıllarda da Ankara ve Samsun tohum 1slah istasyonları faaliyete geçmiş, 1926'da yurt dışından "anaçlık" pancar tohumluğu ilk defa ithal edilmiştir. 1935 yılında ilk yerli buğday ve arpa çeşitleri elde edilmiş ve çiftçiye dağıtılmıştır. 1950 yılında Devlet Üretme Çiftlikleri (Tarım İşletmeleri Genel Müdürlüğü-TİGEM) kurulmuş ve ıslah edilen tohumlukların üretimine başlanmıştır (TÜRKTED, 2019). 1953 yılında tahıl tohumluklarının kontrol ve sertifikasyonu için Ankara Üniversitesi Ziraat Fakültesi Bitki Yetiştirme ve Islahı Kürsüsü vazife almış ve çalışmalar 1959 yılına kadar sürdürülmüştür (Kara ve ark., 2014). Aynı dönemlerde 1956 yılında Milli Tohumluk İstişare Komitesi tarafından "Tohumluk Sertifikasyon Talimatnamesi” hazırlanmıştır. 1959 yılında Ankara'da “Tohumluk Kontrol ve Sertifikasyon Enstitüsü” kurulmuş olup ülkemizde ilk olarak araştırma ve geliştirme faaliyetlerinin bir sonucu olarak yeni çeşitlerin ortaya konulması ve bu çeşitlerin tarafsız bir kuruluşça tescil edilmesi gereği üzerine 1960 yılında "Bölge Çeşit Deneme Enstitüsü" kurulmuştur. 1961 yılında ise sektördeki ilk özel kuruluş kabul edilen tohumculuk şirketi "BETA Ziraat ve Ticaret A.Ş” kurulmuştur (Anonim, 2021b). 1963 y1lında 308 Sayılı "Tohumlukların Tescil, Kontrol ve Sertifikasyonu Hakkında Kanun" yürürlüğe girmiş ve tohumlukların sertifikasyonuna ilişkin faaliyetler bu Kanun hükümlerine göre yürütülmeye başlanmıştır. Ülkemiz, 1963 yılında ISTA’ya (Uluslararası Tohum Test Birliği) üye olmuş, 1968 yılında ise (tarla bitkileri ve yem bitkileri kategorilerinde olmak üzere) OECD (Ekonomik Kalkınma ve İşbirliği Teşkilatı) sertifikasyon sistemine katılmıştır. 1960-1985 yılları arasında resmi tedarik sistemi ile tohumlukların ülkeye girişi ve kaydı yapılmıştır.

Bugünkü adını 1987 yılında alan Tohumluk Tescil ve Sertifikasyon Merkez Müdürlüğ̈̈nün yeniden yapılanması, 1998 yılında FIS/ISF üyeliği, izleyen y1llarda diğer örgütlere üyelikler, özel sektöre verilen destek ve araştırma izinleri ile sektör gelişimini sürdürmüştür (Çelik ve Nazlı 2014; TÜRKTOB, 2017). Cumhuriyetin kuruluşundan 2004 y1lına kadar yaşanan gelişmeler sonucunda tohumculukla ilgili mevzuat ihtiyaçlara cevap veremediği için ülkemiz 1973 yılında ilk kez 1slahçı hakları ile ilgili yasal bir düzenlemede yer almıştır. 2004 yılında "5042 sayılı Yeni Bitki Çeşitlerine Ait Islahçı Haklarının Korunmasına İlişkin Kanun" ve 2006 yılında "5553 sayılı Tohumculuk Kanunu” kabul edilmiş ve bu kanunlar ile sektördeki pek çok sorun çözüme kavuşturulmuştur. 2007 y1lında 5601 Sayılı Kanun ile UPOV (Uluslararası Yeni Bitki Çeşitlerini Koruma Birliği) üyeliği gerçekleştirilmiştir. 2008 yılında Tohumculuk Kanunu'na istinaden çıkarılan 26755 sayılı Bitki Çeşitlerinin Kayıt Altına Alınması Yönetmeliği kapsamında ve UPOV sözleşmesi çerçevesinde sebze çeşitlerinde kayıt işlemleri yapılmaya başlanmıştır.

Bu çalışma ile ülkemizde bugüne kadar kayıt altına alınan sebze çeşitlerinin hem üretim izni, tescil, ıslahçı hakları kapsamında değerlendirilmesi hem de mevcut durumu hakkında bilgi verilmeye çalışılmıştır.

\section{Tescil Edilen Sebze Çeşitlerinin Mevcut Durumu}

Ülkemizde 5553 sayılı Tohumculuk Kanunu gereği yalnızca kayıt altına alınmış tohumlukların ticaretine izin verilmektedir. Tohumluk üretmek isteyen asıl veya tüzel kişilerin; Tohumluk Yetiştirici, Üretici veya Özel Sektör Araştırıcı Kuruluş Yetki Belgesi almış olmaları gerekmektedir. (Anonim, 
2018a). Tohumluk üretimi konusunda görevlendirilen kamu kuruluşları ile tohumluk üretmek amacıyla kurulmuş olan, bu konuda gerekli alt yapısı bulunan fiilen sertifikalı ya da standart tohumluk üreten 993 özel şirketin 225'i sebze türlerinde tohumluk üretimi yapan tohumluk üreten özel sektör kuruluşlarıdır. Bakanlık araştırma kuruluşları haricinde 2021 yılı itibariyle tohumluk ile ilgili 1slah, araştırma, geliştirme ve deneme yapan özel sektör tarımsal araştırma kuruşlu 129'u bulmuştur (Anonim, 2021c).

Yurt içinde veya yurt dişında sslah edilen veya bulunan ve geliştirilen bitki çeşitlerinin farklı, yeknesak ve durulmuş olduğunun tespit edilerek kütüğe kaydedilmesi işlemi çeşit tescili olarak tanımlanmaktadır (Anonim, 2008). Ülkemizde sebze kayıt çeşit sisteminde 1963, 1991 ve 2008 yılları önemli değişimlerin olduğu yıllar olarak bilinmektedir. 1963 yılında performans esasına dayalı bir tescil sistemi yer alırken, 1991 yılında "Ticari Sebze Tohumluk Kaydı” modeli ile çeşit özellik belgeleri doldurularak çeşitlerin hızlı biçimde piyasaya girmesi sağlanmıştır (Çelen ve ark., 2020).

Sebze çeşitlerinde kayıt işlemlerinin tüm mekanizmaları Tarım ve Orman Bakanlığı adına “Tohumluk Tescil ve Sertifikasyon Merkez Müdürlügü̈ tarafından yürütülmektedir. Çeşitlerin kayıt altına alınması için morfolojik karakterlerin belirlenerek çeşit kimliğinin ortaya konulması gerekmektedir. Çeşidin tanımlanmasında ve ayrımında kullanılan bazı çeşit özellik belgeleri geliştirilmiş, ülkeler arasında çeşit özellik belgeleri konusunda metot birliği oluşturması için UPOV tarafından çeşit özellik belgeleri oluşturulmuştur. 2008 yılında çıkarılan Bitki Çeşitlerinin Kayıt Altına Alınması Yönetmeliği Avrupa Birliği Uyum çerçevesinde hazırlanmış olup, bu aşamada aday çeşit için FYD (Farklılık, Yeknesaklık, Durulmuşluk) testi gerçekleştirilmektedir. Bu test; belirli bir çeşidin tüm morfolojik ve fizyolojik karakteristiklerinin kayıt, koruma, kimliklendirme ve sertifikasyona esas olmak üzere kaydedilmesi ve belgelendirilmesinden oluşmaktadır. Bitki Çeşitlerinin Kayıt Altına Alınması Yönetmeliğinde;

- Farklılık; Çeşidin, tescile başvurusunun yapıldığı tarihte kayıtlı olan diğer çeşitlerden en az bir ya da birkaçı bakımından açıkça ayırt edilebilmesi,

- Yeknesaklık; Çeşidin çoğaltılması sırasında, çoğaltma yöntemine bağlı olarak beklenen varyasyonun dışındaki diğer özellikler yönünden yeterince homojen olması,

- Durulmussluk; Çeşidin tekrarlanan üretimlerden sonra veya belirli üretim devreleri sonunda ilgili özellikler yönünden değişmeden kalması olarak adlandırılmaktadır (Anonim, 2008).

Bir sebze çeşidi kayıt altına alınırken Tohumluk Tescil ve Sertifikasyon Merkez Müdürlüğü’ne başvurulan çeşitlerin kabul edilmesi ve incelenmesi ile başlayan süreç söz konusu çeşitlere üretim izni verilerek bu süreç içerisinde çeşidin piyasaya sürülerek çiftçilere ulaştırılması sağlanmaktadır. Üretim izni verilen çeşitlere tescil süresince FYD testlerinin planlanması ve deneme setlerinin hazırlanması ile devam edilmektedir. FYD testleri kurulduktan sonra ilgili çeşitlere ait tüm gözlemler UPOV çeşit özellik belgeleri temel alınarak yapılmaktadır. Deneme sonunda 1. ve 2. yıl alınan tüm verilerek değerlendirilerek çeşit eğer diğer çeşitlerden farklı, durulmuş ve yeknesak olduğu belirlenirse tescil raporları hazırlanarak tescil komitesinde tartışılması ve çeşit isminin bu komitede bir kez daha onaylanarak çeşit özellik belgelerinin oluşturularak başvuru sahibine/1slahçıya gönderilmesi ile tamamlanmaktadır. Sebze çeşitleri için üretim izni ve tescil komitesi toplantıları her yılın Şubat, Mayıs ve Ekim aylarında yapılmaktadır (Anonim, 2012).

Kayıt altına alınma işlemleri 1964 yılında kamu ağırlıklı bir sebze tescil süreci ile başlamış bu yılda 13 domates, 7 fasulye, 3 patlıcan, 2'şer biber, havuç ve bezelye, 1'er de 1spanak, karpuz, kırmızı pancar, marul ve pırasa olmak üzere toplam 34 çeşit Bakan Olur'u ile kayıt altına alınmıştır. 1963 yılında kabul edilen 308 sayılı Tohumculuk Kanunu ile kayıt altına işlemleri kapsamında 3001, 2008 yılında 5553 yılında Tohumculuk Kanunu kapsamında ise 3861 sebze çeşidi kayıt altına alınmıştır. Onar yıllık dilimlerde kayıt altına alınan sebze çeşitleri incelendiğinde; 1964 ile 1981 yılları arsında 52, 1982 ile 
1992 y1lları arasında 209, 1993 ile 2002 yılları arasında 1426, 2003-2008 y1lları arasında 1408 adet sebze çeşidi kayıt altına alınırken, 2008 yılından günümüze kadar FYD testleri yapılarak 3861 sebze çeşidi kayıt altına alınmıştır.

Günümüzde sebze tipleri olarak kabul edilen isimlendirmelerden bazıları aslında o tipi temsilen ilk kayıt altına alınan çeşitlerin adlarıdır. 1964 yılı ile başlayan bu süreçte tip halinde geçerlilik kazanan sebze çeşitlerinin bazıları Çizelge 1'de verilmiştir.

Çizelge 1. 1964 yılından günümüze tip ismi haline dönüşen bazı sebze çeşitleri

\begin{tabular}{llll}
\hline Tür Adı & Çeşit Adı & Başvuru Sahibi Kuruluş & Tescil Tarihi \\
\hline Biber & Çarliston 52 & Batı Akdeniz Tar. Arşt. Ens. Müd. & 16.05 .1964 \\
Biber & Dolma Biber 14 & Geçit Kuşağı Tar. Arşt. Ens. Müd. & 16.05 .1964 \\
Biber & Kandil Dolma & Atatürk Bahçe Kült. Mrk.Arşt.Ens.Müd. & 26.04 .1984 \\
Biber & Yalova Tatlı Sivri & Atatürk Bahçe Kült. Mrk.Arşt.Ens.Müd. & 26.04 .1984 \\
Biber & Yalova Yağlık 28 & Atatürk Bahçe Kült. Mrk.Arşt.Ens.Müd. & 27.04 .1988 \\
Biber & Yalova Çorbacı 12 & Atatürk Bahçe Kült. Mrk.Arşt.Ens.Müd. & 29.04 .1991 \\
Biber & Sera Demre 8 & Batı Akdeniz Tar. Arşt. Ens. Müd. & 01.04 .1994 \\
Havuç & Nantes & Tarla Bitkileri Mrk.Arşt.Ens.Müd. & 16.05 .1964 \\
Hıyar & Çengelköy Hıyarı 5802 & Atatürk Bahçe Kült. Mrk.Arşt.Ens.Müd. & 16.04 .1968 \\
Hiyar & Beith Alpha & Geçit Kuşağ1 Tar. Arşt. Ens. Müd. & 29.04 .1991 \\
Karpuz & Crimson Sweet & May-Agro Tohumculuk San. ve Tic. A.Ş̧ & 14.05 .1992 \\
Kavun & Ananas & Batı Akdeniz Tar. Arşt. Ens. Müd. & 26.04 .1984 \\
Kavun & Hasan Bey & Ege Tar. Arşt. Ens. Müd. & 24.04 .1985 \\
Kavun & Kırkağaç 589 & Ege Tar. Arşt. Ens. Müd. & 24.04 .1985 \\
Kavun & Kırkağaç 637 & Ege Tar. Arşt. Ens. Müd. & 24.04 .1985 \\
Patlıcan & Kemer 27 & Trakya Tar. Arşt. Ens. Müd. & 16.05 .1964 \\
Patlıcan & Topan 374 & Ege Tar. Arşt. Ens. Müd. & 16.05 .1964 \\
Patlıcan & Pala-49 & Atatürk Bahçe Kült. Mrk.Arşt.Ens.Müd. & 26.04 .1984 \\
Pirasa & İnegöl 92 & Atatürk Bahçe Kült. Mrk.Arşt.Ens.Müd. & 14.05 .1992 \\
Fasulye & Barbunya 5702 & Trakya Tar. Arşt. Ens. Müd. & 16.05 .1964 \\
Fasulye & 40 Günlük & Geçit Kuşağ1 Tar. Arşt. Ens. Müd. & 24.04 .1985 \\
\hline
\end{tabular}

Ülkemizde farklı sebze türlerinde üretimi yapılan çeşit sayısı her geçen gün artış göstermektedir. Bugüne kadar 40 bitki türünde 6877 sebze çeşidi kayıt altına alınmıştır (Anonim, 2021d). En çok sayıda çeşit kaydının yapıldığı türler sırasıyla domates, hıyar, biber, marul, karpuz, kavun, taze fasulye, kabak ve karnabahardır (Çizelge 2). Sebze çeşitlerinin 6618 tanesi özel, 248 tanesi kamu ve 11 tanesi de üniversite adına kayıt altına alınmıştır. Son yıllarda yılda ortalama 300 civarında sebze çeşidi kayıt altına alınmaktadır. Bunun en önemli nedenleri, tarımsal üretimde genişleyen ve hızla değişen pazar ve tüketici talepleri ile yurt içi ve yurt dışı özel bitki 1slah çalışmalarından kaynaklanan rekabetçi çeşit tedarik sistemidir. Kayıt altına alınan çeşitlerin \%67.8 yurtdışı, \%32.2 yerli firmaların çeşitlerinden oluşmaktadır.

Yurt içinde veya yurt dışında 1slah edilen veya bulunan ve geliştirilen bitki çeşitlerinin biyolojik ve teknolojik özellikleri ile hastalık ve zararlılara dayanıklılığının ve tarımsal özelliklerinin tespit edilerek, çeşit tescil edilinceye kadar verilen süreli izni üretim izni olarak tanımlanmaktadır (Anonim, 2008). İlgili yönetmelik gereği üretim izni alan çeşitlerde 2 vejetasyon süresince farklılık, yeknesaklık ve durulmuşluk testleri yapılmaktadır. 2021 yılı itibariyle üretim izni verilen türlere ait çeşit sayıları Çizelge 3'te verilmiştir. Buna göre domates, biber ve hıyar, üretim izni alan çeşitler arasında ilk üç sırayı almaktadır. 
Çizelge 2. Kayıt altına alınan sebze çeşitleri ile özel, kamu ve üniversite içindeki payı

\begin{tabular}{|c|c|c|c|c|c|c|c|c|c|}
\hline Tür & Özel & Kamu & Ünv. & Toplam & Tür & Özel & Kamu & Ünv. & Toplam \\
\hline Domates & 1745 & 51 & - & 1796 & Bakla & 26 & 1 & - & 27 \\
\hline Hiyar & 859 & 7 & - & 866 & K. Pancar & 21 & 1 & - & 22 \\
\hline Biber & 780 & 41 & 1 & 822 & Enginar & 18 & 4 & - & 22 \\
\hline Marul & 396 & 13 & - & 409 & Tere & 15 & - & 1 & 16 \\
\hline Karpuz & 355 & 7 & - & 362 & Roka & 15 & - & - & 15 \\
\hline Kavun & 336 & 15 & 3 & 354 & Kereviz & 13 & 1 & - & 14 \\
\hline Fasulye & 274 & 30 & - & 304 & Alabaş/Şalgam & 14 & - & - & 14 \\
\hline Kabak & 285 & 9 & - & 294 & Dereotu & 12 & - & - & 12 \\
\hline Karnabahar & 243 & 7 & - & 250 & P1rasa & 9 & 2 & - & 11 \\
\hline Lahanalar & 203 & 8 & 1 & 212 & Semizotu & 11 & - & - & 11 \\
\hline Ispanak & 184 & 4 & - & 188 & Maydanoz & 9 & - & - & 9 \\
\hline Soğan & 177 & 6 & - & 183 & Paz1 & 6 & - & - & 6 \\
\hline Patlican & 164 & 14 & 1 & 179 & Bamya & 2 & 4 & - & 6 \\
\hline Havuç & 118 & 2 & - & 120 & Sarımsak & - & 3 & - & 3 \\
\hline Brokoli & 93 & - & - & 93 & Rezene & 3 & - & - & 3 \\
\hline Bezelye & 82 & 8 & 1 & 91 & Kuşkonmaz & 2 & - & - & 2 \\
\hline Şeker/cin misır & 61 & 5 & - & 66 & Kuzukulağı & 2 & - & - & 2 \\
\hline Turp & 53 & 4 & 1 & 58 & Nane & 1 & - & - & 1 \\
\hline
\end{tabular}

Çizelge 3. 2021 yılında üretim izni verilen türlere ait çeşit sayıları

\begin{tabular}{ll}
\hline Türler & Çeşit sayısı \\
\hline Domates & 421 \\
Biber & 241 \\
Hiyar & 116 \\
Kabak & 49 \\
Kavun & 26 \\
Karpuz & 45 \\
Marul & 19 \\
Patlican & 52 \\
Soğan & 92 \\
Taze fasulye & 45 \\
Lahanagiller & 34 \\
Diğer & 72 \\
Toplam & $\mathbf{1 2 1 2}$ \\
\hline
\end{tabular}

Ülkemizde bitki çeşitlerinin korunması ve sslahçı hakları ile ilgili tüm uygulamalar 5042 kanun kapsamında Tarım ve Orman Bakanlığı tarafından yürütülmektedir. Bitki çeşitlerinin korunması için başvuruların kabul edilmesi ve değerlendirilmesinde Bitkisel Üretim Genel Müdürlüğü, FYD (Farklılık, Yeknesaklık, Durulmuşluk) testleri ve diğer teknik işlemleri yürütmek üzere teknik inceleme kuruluşu olarak da Tohumluk Tescil ve Sertifikasyon Merkezi Müdürlüğ̈ (TTSMM) Bakanlık tarafindan görevlendirilmiştir (Ermiş ve ark., 2010).

Islahçı hakları kapsamında 19 özel, 457 kamu ve üniversiteye ait sebze çeşit adayı başvurusu yapmıştır. Ülkemizde uygulanan bu sistemde bugüne kadar 14 özel, 275 kamu olmak üzere toplam 289 çeşidin ıslahçı hakları kapsamında tescili tamamlanmıştır. Islahçı hakları kapsamında Tescili tamamlanan sebze çeşitlerinin 54 tanesi yerli, 235 tanesi ise yurtdışında ıslah edilmiştir. 


\section{SONUÇ}

Ülkemiz sebze tohumu sektörünün, tescil aşamasından başlayarak uzun yılların deneyimi ile inceleme değerlendirme ve güncelleştirilmesine devam edilmelidir (Çelen ve ark., 2020). 1925 y1lından itibaren açılan tohum ıslah istasyonları ile başlayan süreç 1953 yılında tahıl tohumluklarının kontrol ve sertifikasyonu ile devam ederek 1986 yılında kurulmuş olan Tohumluk Tescil ve Sertifikasyon Merkez Müdürlüğ̈̈'nün kurulması ile perçinlenmiştir. Bu yıldan günümüze kadar gelen bilgi birikimi ve tecrübe ile yapılacak olan yeni değişimler ile ülkemiz tohumculuk sektörüne katkı sağlayacaktır. Gelinen bu noktada, Bitki Çeşitlerinin Kayıt Altına Alınması Yönetmeliği'nde yapılacak olan köklü değişiklikler ile başta ülkemiz çiftçileri olmak üzere sektör, paydaş ve tohumculuk sektörüne yeni bir ivme kazandırılacağı da aşikârdır.

Ülkemizde, özellikle sebze tohumculuğu sektöründe hem yerli hem de yabancı firmalar sürekli olarak yeni yatırımlar yapmakta olup her geçen gün yeni sebze çeşitleri geliştirmekte ve bu çeşitler kayıt altına alınmaktadır (Balkaya ve ark., 2020). Ülkemiz UPOV üyesi ülkelerin çeşit özellik belgelerini hem 1slahçı hakları hem de kayıt altına alma işlemlerinde kabul etmektedir (Anonim, 2008; Çelen ve Erçik, 2020). Ancak ülkemizin oluşturduğu teknik inceleme raporları, FYD raporlarını kabul ettiğimiz bazı ülkeler tarafından kabul edilmemektedir (Çelen vd., 2020). Kayıt altına alma işlemlerinde özellik belgesinin yaklaşık \%20'lik kısmını hastalık ve zararlılara dayanım oluşturmaktadır. Ülkemizde FYD testlerinde maalesef hastalık ve zararlıların testlemelerine ilişkin bir karakterizasyon yapılmamaktadır. Tohumluk Tescil tarafindan doldurulan çeşit özellik belgelerinin belirli türlerden başlayarak hastalık testlemelerinin yapılması ve karşılıklılık ilkesi kapsamında hareket edilerek tüm UPOV üyesi ülkelerde geçerli sayılabilmesi hem tescil edilen türler hem de ülke ülkemiz prestiji açısından son derece önemlidir.

Fikri-sınai mülkiyet hakları çerçevesinde, 'genetik kaynak', 'gen patenti', 'bitki patenti', 'bitki çeşidi', 'esastan (bir başlangıç çeşidinden) türetilmiş çeşitler', vb. konularda politikaların oluşturulması, yeni çeşitlerin mutlaka koruma altına alınması ile ilgili bilgilendirmelerin yapılması, ülkemizin zengin biyolojik çeşitliliğinin ve bitki gen kaynaklarının korunması ve kayıt altına alınması, kayıtlı kaynaklara bitki ıslahçılarının birçok ülkede olduğu gibi kolayca erişiminin sağlanması ile ilgili tedbirler alınmalıdır (Anonim, 2018b).

Ülkemiz sebze tohumculuğu sektöründe üretim izni aşamasından başlayarak tescil ve sslahçı haklarına kadar, güncellemeleri ve değişikliği sağlanmalıdır. Bu adımların atılmasının temelinde de hiç şüphesiz tohum ve tohumculuğa gereken değerin verilmesi ve bu kapsamda gerekli politikaların oluşturulması gerekmektedir.

\section{Çıkar Çatışması}

Makale yazarları arasında herhangi bir çıkar çatışması olmadığı beyan olunur.

\section{Yazar Katkısı}

Makaleye yazarlar eşit oranda katkı sağlamışlardır.

\section{KAYNAKLAR}

Anonim, 2008. Bitki Çeşitlerinin Kayıt Altına Alınması Yönetmeliği (R.G. 13.01.2008/26755).

Anonim, 2012. Bitki Çeşitlerinin Kayıt Altına Alınması Yönetmeliğinde Değişiklik Yapılmasına Dair Yönetmelik (R. G. 12.05. 2012/28290).

Anonim, 2016. Tohumculuk 2015. Gıda Tarım ve Hayvancılık Bakanlığı, Eğitim Yayım ve Yayınlar Dairesi 
https://www.tarimorman.gov.tr/BUGEM/Belgeler/Duyurular/tohumculuk.pdf. (Erişim Tarihi: 29.10.2021).

Anonim, 2018a. Tohumculuk Sektör Politika Belgesi 2018-2022 https://www.tarimorman.gov.tr/TAGEM/Belgeler/yayin/Tohumculuk\%20Sekt\%C3\%B6r\%20Politika \%20Belgesi\%202018-2022.pdf (Erişim Tarihi: 02.11.2021).

Anonim, 2018b. Tarım ve Gıdada Rekabetçi Üretim Özel İhtisas Komisyonu Raporu. https://www.sbb.gov.tr/wpcontent/uploads/2020/04/Tarim_ve_GidadaRekabetciÜretimÖzelïhtis asKomisyonuRaporu.pdf. (Erişim Tarihi: 29.10.2021).

Anonim, 2019. Uluslararası Tohum Federasyonu Tohumculuk İstatistikleri. https://www.worldseed.org/resources/seed-statistics. (Erişim Tarihi: 02.11.2021).

Anonim, 2021c. Bitkisel Üretim Genel Müdürlüğü Verileri. https://www.tarimorman.gov.tr/Konular/ Bitkisel-Uretim/Tohumculuk/Ozel-Sektor-Tarimsal-Arastirma-Kuruluslari (Erişim tarihi: 02.11.2021).

Anonim,2021a. https://www.marketsandmarkets.com/Market-Reports/seed-market-126130457.html. (Erişim tarihi: 07.11.2021).

Anonim,2021b. Beta Ziraat ve Ticaret A.Ş. Hakkında, http://betaziraat.com.tr/Tr/kurumsal. (Erişim Tarihi: 25.10.2021).

Anonim, 2021d. Tohumluk Tescil ve Sertifikasyon Merkez Müdürlüğü Verileri, Ankara.

Balkaya A, Duman İ, Arın L, Özcan M, Demir İ, Kandemir D, Zengin S, Ermiş S, ve Sarıbaş Ş, 2020. Bahçe Bitkilerinde Tohum Üretimi; Mevcut Durum ve Gelecek, Türkiye Ziraat Mühendisliği IX. Teknik Kongresi Bildiriler Kitab1, 13-17 Ocak 2020, Cilt II, s: 339-370. Ankara.

Çelen H, Ermiş S, Ata A, 2020. Avrupa Birliği ve Türk Sebze Çeşit Tescili Mevzuatlarının Karşılaştırılması. WOJHENS World Journal of Health\& Natural Sciences, 2.

Çelen H, Erçik K, 2020. Türk Bitki Islahçı Hakları Sistemi. Uluslararası Anadolu Ziraat Mühendisliği Bilimleri Dergisi, 2(1):34-43.

Çelik Y, Nazlı T, 2014. Konya İlinde Sertifikalı Tohumluk Üreten İşletmelerin Yapısal Analizi. Türk Tarım ve Doğa Bilimleri Dergisi, 1(2): 124-131.

Ermiş S, Yılmaz K, Özden ŞY, Güney E, 2010. Ülkemizdeki Sebze Türlerinde Bitki Islahçı Haklarının Uygulanması ve UPOV Sistemi. VIII. Sebze Tarımı Sempozyumu. s: 1-5 Van.

Kara S, Benlioğlu B, Güler M, 2014. Türkiye Tahıl Tohumculuğunun Durumu. Türkiye 5. Uluslararas1 Katılımlı Tohumculuk Kongresi, 19-23 Ekim 2014, Diyarbakır.

TİGEM, 2019. Tarım İşletmeleri Genel Müdürlüğü 2019 Yılı Tohumculuk Sektör Raporu, https://www.tigem.gov.tr/WebUserFile/DosyaGaleri/2018/2/a374cc25-acc1-44e8-a54663b4c8bce146/dosya/2019\%20YILI\%20TOHUMCULUK\%20SEKTOR\%20RAPORU.pdf. (Erişim tarihi: 02.11.2021).

TÜRKTED, 2019. Türkiye Tohumculuk Endüstrisi Derneği Ürün Grupları Bazlı Türkiye Tohumculuk Sektörü Raporu. http://turkted.org.tr/urun-gruplari-bazli-turkted-raporu.pdf. (Erişim Tarihi: 12.11.2021).

TÜRKTOB, 2017. Türkiye Tohumcular Birliği Tohumculuk Sektörü Ulusal Strateji Raporu 2017. https://www.turktob.org.tr/uploads/plugo/TURKTOB\%20-20TOHUMCULUK\%20SEKTORU \%20ULUSAL\%20STRATEJI\%20RAPORU.pdf. (Erişim Tarihi: 30.10.2021).

TÜRKTOB, 2020. Türkiye Tohumcular Birliği Tohumculuk Sektör Raporu 2020. https://turktob. org.tr/upload/2020_TOHUMCULUK_SEKTOR_RAPORU-.pdf. (Erişim Tarihi: 30.10.2021). 